\title{
Anthelmintic and nutritional effects of heather supplementation on Cashmere goats grazing perennial ryegrass-white clover pastures ${ }^{1}$
}

\author{
K. Osoro, ${ }^{*}$ A. Mateos-Sanz, $\dagger$ P. Frutos, $\neq$ U. García,* L. M. Ortega-Mora, $\dagger$ \\ L. M. M. Ferreira, $§$ R. Celaya, ${ }^{*}$ and I. Ferre $\dagger^{2}$
}

*Servicio Regional de Investigación y Desarrollo Agroalimentario (SERIDA), Área de Sistemas de Producción Animal, Consejería de Medio Rural y Pesca, Principado de Asturias, 33300 Villaviciosa, Spain; $\dagger$ Departamento de Sanidad Animal, Facultad de Veterinaria, Universidad Complutense de Madrid, Ciudad Universitaria s/n, 28040 Madrid, Spain; \$Estación Agrícola Experimental, Consejo Superior de Investigaciones Científicas (CSIC), Finca Marzanas, 24346-Grulleros, León, Spain; and §CECAV, Departamento de Zootecnia, Universidade de Trás-os-Montes e Alto Douro, PO Box 1013, 5000-911 Vila Real, Portugal

\begin{abstract}
To investigate anthelmintic and nutritional effects of heather supplementation in goats grazing perennial ryegrass-white clover pastures, 40 dry Cashmere goats were randomly assigned to 4 treatments in a $2 \times 2$ factorial arrangement: 2 grazing management treatments (supplementation with heather vs. nonsupplementation) and 2 anthelmintic treatments (treatment vs. nontreatment). Goats grazed continuously from May to September 2004. At the end of the grazing period, the number of dead goats due to gastrointestinal parasitism was 1 in the group supplemented with heather and dosed with anthelmintic, 4 in the group that received neither supplementation nor anthelmintic, and 0 in the other 2 groups. For goats that did not receive anthelmintic treatment, the percentage
\end{abstract}

of heather in the diet was negatively correlated with fecal egg count in August $(\mathrm{r}=-0.59, P<0.05)$ and September $(\mathrm{r}=-0.49, P<0.1)$ and positively correlated ( $\mathrm{r}=0.54, P<0.05)$ with $\mathrm{BW}$ changes during the grazing season. Therefore, the correlation coefficient between BW change and fecal egg count was negative $(r=-0.62$, $P<0.05$ ). Rumen ammonia concentrations were always lower in supplemented goats $(P<0.05)$. However, VFA concentrations were greater in goats consuming heather (58.9 vs. $50.9 \mathrm{mmol} / \mathrm{L})$, which suggests that ruminal fermentation was not adversely affected by consumption of tannins. Heather availability in the vegetation might represent a valuable opportunity and sustainable method to control gastrointestinal nematode infections in a goat production system based on grazing perennial ryegrass-white clover pastures.

Key words: Cashmere goat, gastrointestinal nematode, grazing, heather, body weight, ruminal fermentation

(C)2007 American Society of Animal Science. All rights reserved.

J. Anim. Sci. 2007. 85:861-870

doi:10.2527/jas.2006-388

\section{INTRODUCTION}

Heather species (Erica spp., Calluna vulgaris) are important vegetation components of mountainous ecosystems, mainly grazed by sheep and goats (Osoro et al., 1999). The presence of grass species in the heathlands that is required to meet animal requirements has been related to gastrointestinal nematode parasitism

\footnotetext{
${ }^{1}$ The authors would like to thank the Carbayal Research Station staff for their help in the field work. L. M. M. Ferreira was funded by the Portuguese Foundation for Science and Technology (doctoral grant SFRH/BD/16833/2004).

${ }^{2}$ Corresponding author: iferrepe@vet.ucm.es

Received June 15, 2006.

Accepted October 28, 2006.
}

(Osoro et al., 1995), a disease having a major detrimental effect on the efficiency of production by grazing ruminants (Sykes, 1994). Constant increases in anthelmintic drug resistance worldwide (Jackson and Coop, 2000) have encouraged the search for alternative approaches less reliant on chemotherapy (Waller, 1999).

Parasite-infected goats consuming moderate quantities of plants containing tannins have shown reductions in fecal egg counts (Paolini et al., 2003a,b,c, 2005; Hoste et al., 2005; Min et al., 2005), as recently reported in Cashmere and Celtiberic goats naturally infected by Trichostrongylus, Teladorsagia, and Oesopahgostomum nematode genera, fed on tannin-containing heather (Frutos et al., 2002; Osoro et al., 2007). However, tannins are primarily known for their antinutritional effects (McLeod, 1974; Makkar, 2003). Some authors suggested that a net benefit from ingestion of 
tannins could only be achieved when their anthelmintic (positive) effects outweigh their antinutritional (negative) consequences (Houdijk and Athanasiadou, 2003). On the other hand, tannins may benefit ruminant nutrition by reducing ruminal protein degradation (Barry and McNabb, 1999; Frutos et al., 2000).

The objective of the current study was to investigate the anthelmintic and nutritional effects of heather supplementation in nonlactating Cashmere goats grazing perennial ryegrass-white clover pastures and the possible relationship between heather intake, fecal egg count, and BW changes. The study was carried out under practical conditions in a less favored area, where grazing animals are extensively raised and included in the dynamic of a natural ecosystem.

\section{MATERIALS AND METHODS}

\section{Experimental Site}

The experiment was carried out in a mountainous area (1,000 $\mathrm{m}$ above sea level) in the northwest of Spain $\left(6^{\circ} 53^{\prime} \mathrm{W}, 43^{\circ} 21^{\prime} \mathrm{N}\right.$; Sierra de San Isidro, Illano, Asturias), where shrubby heather-gorse vegetation is dominant. Four plots of $5,000 \mathrm{~m}^{2}$ each were established, in which the vegetation had been improved in 2001 by soil ploughed and dressing and sowing perennial ryegrass (Lolium perenne L.) and white clover (Trifolium repens L.), and removing any heather that was present.

Annual rainfall in the experimental year (2004) was $1,589 \mathrm{~mm}$. During the grazing season, mean rainfall ranged from 36 to $111 \mathrm{~mm} / \mathrm{mo}$. Mean average temperatures were $17.3^{\circ} \mathrm{C}$ in June and $10.6^{\circ} \mathrm{C}$ in May.

\section{Animals}

The experiment was carried out in accordance with the European Council Directive 86/609/ECC for the protection of animals used for experimental and other scientific purposes.

Ten nonlactating goats (Cashmere breed) were allocated to each plot on 25 May. They were reared outdoors under pasture conditions, not excluding nematode infections. The mean live BW of the goats at the beginning of the experimental period was $31.2 \pm 0.88 \mathrm{~kg}$. Two weeks before the experiment began, all animals were dosed orally against gastrointestinal nematodes with ivermectin (Oramec, Merial, Lyon, France) at twice the recommended rate $(2 \mathrm{mg} / \mathrm{kg}$ of $\mathrm{BW})$.

\section{Experimental Design}

Forty dry Cashmere goats were blocked by BW and body condition and randomly assigned to 1 of 4 treatment groups in a $2 \times 2$ factorial arrangement. Main effects were grazing management treatment (supplementation with heather vs. nonsupplementation) and anthelmintic treatment (treatment vs. nontreatment). Supplemented groups were offered freshly cut heather ad libitum, every $3 \mathrm{~d}$, in the morning, whereas the others received no supplement. Goats treated with anthelmintic were dosed orally with ivermectin $(2 \mathrm{mg} / \mathrm{kg}$ of BW, Oramec, Merial, Lyon, France) every 2 mo, whereas the others received no treatment. Each treatment group was allocated to 1 of the 4 plots described previously. All goats grazed continuously throughout the whole experimental period. The experiment was conducted from 25 May to 14 September 2004.

\section{Measurements and Procedures}

Pasture. To control grass availability, the sward surface height was measured weekly using a HFRO swardstick (Barthram, 1986), taking 100 measurements at random in each plot. Botanical composition of the pasture was assessed during the summer (July) using a point quadrat (Grant, 1981) and recording 100 vertical hits at random in each plot. Pasture sampled in July was analyzed for ash and N (AOAC, 1990). Crude protein was calculated as $\mathrm{N} \times 6.25$. Neutral and acid detergent fiber and ADL were analyzed by the method of Goering and van Soest (1970) and van Soest et al. (1991).

Heather. Samples of the green shoots (less than 3 $\mathrm{mm}$ in diam.) of the heather offered to the goats were collected weekly for determination of botanical composition and monthly for chemical composition. All samples were sorted into individual botanical species before being freeze-dried and ground $(0.5 \mathrm{~mm})$. The nutritive quality (ash, $\mathrm{CP}, \mathrm{NDF}, \mathrm{ADF}$, and $\mathrm{ADL}$ ) of the green shoots (i.e., those parts expected to be consumed by the goats) of pooled heather samples was analyzed for chemical composition following the same procedures mentioned for the pasture.

Heather offered to the supplemented goats was also analyzed every $15 \mathrm{~d}$ for total tannins. Assays were carried out following the Folin-Ciocalteu assay in combination with polyvinyl-polypyrrolidone (PVPP), as described by Makkar et al. (1993). After removing pigments and fats, total phenols were extracted using aqueous acetone $(70 \%)$. The extract of total phenols was then treated with PVPP. After centrifugation, PVPP forms a precipitate with tannins, and the supernatant has only simple phenols. Content of total phenols in the first extract (before treatment with PVPP), and simple phenols in the second extract (after treatment with PVPP), were determined using the Folin-Ciocalteu reagent and tannic acid (Merck, Damstadt, Germany) as the reference standard. The difference between total and simple phenol values represents the total tannin content, expressed as tannic acid equivalents.

The percentage of heather in the diet of each individual goat was estimated in June and September using the n-alkane method (Mayes et al., 1986), as modified by Oliván and Osoro (1999). Samples of pasture, heather, and feces were collected at each sampling. Calculations were performed using a least squares optimization procedure, which minimizes the discrepancies 
between the actual concentration of alkanes in feces (adjusted for incomplete fecal recoveries, using the recovery values obtained in previous studies by Ferreira et al., 2005) and the estimated proportion in the diet (Dove and Moore, 1995).

Ruminal Fermentation Parameters. After an overnight fast, ruminal fluid was collected from each goat by stomach tube and strained through 2 layers of gauze. Immediately afterwards, $4 \mathrm{~mL}$ was acidified with $4 \mathrm{~mL}$ of $0.2 \mathrm{~N} \mathrm{HCl}$ for ammonia determination, and $8 \mathrm{~mL}$ was deproteinized with $0.5 \mathrm{~mL}$ of $2 \%$ metaphosphoric and $0.4 \%$ crotonic acids (wt/vol) in $0.5 \mathrm{~N} \mathrm{HCl}$ for VFA determination. All samples were stored at $-30^{\circ} \mathrm{C}$ until analysis. Ammonia concentration was determined by a modified colorimetric method (Weatherburn, 1967), and VFA was determined by gas chromatography (Carro et al., 1999), both in centrifuged samples.

Parasitological Procedures. Fecal samples were collected by rectal sampling once monthly from May to August and twice in September to assess gastrointestinal nematode egg excretion. Numbers of gastrointestinal nematode eggs per gram of feces were estimated using the modified McMaster technique (MAFF, 1978) with sodium chloride as the flotation medium, in which 1 egg counted is equivalent to 15 eggs/g of fresh feces. Gastrointestinal nematode genuses present in goat feces were identified monthly on the basis of infective third-stage larvae obtained by coprocultures (van Wyk et al., 2004).

For parasite burden studies, the abomasum and intestine of goats that died during the experimental period were removed, tied at the omasum, pylorus, terminal ileum, and rectum, and frozen until analysis. Organs were later thawed and washed thoroughly to remove all digesta and nematodes; and 5\% aliquots of washings were taken, rinsed through a $60-\mu \mathrm{m}$ sieve, and preserved in $10 \%$ formalin for nematode counting. The genus, number, and sex of the worms recovered from each goat were determined.

Body Weight and Body Condition Score. All animals were weighed at the beginning and end of the experimental grazing season and also at monthly intervals. At the same time, the BCS of goats was assessed on a scale of 1 to 5 ( $1=$ emaciated, 5 = fat; Russel, 1990). To study BW changes and the possible relationship with other variables (fecal egg count, heather intake, etc.), grazing season was divided into 2 periods: period 1 from 25 May to 2 August (high sward availability), and period 2 from 2 August to 14 September (low sward availability).

\section{Statistical Analysis}

Data were subjected to ANOVA to evaluate the effects of the 2 main factors, heather supplementation and anthelmintic treatment and their interaction, in a completely randomized design, on fecal egg count, rumen fermentation parameters, and BW and BCS changes of goats during the experimental grazing season. Data on eggs per gram of feces were log transformed $\left(\log _{10} X+1\right)$ to normalize their distribution. Correlation coefficients between heather percentage in the diet, ammonia concentration in the rumen, fecal egg count, and BW changes were also studied by bivariate Pearson linear correlation. The mortality rate in the different treatments was analyzed by $\chi^{2}$ test. All statistical analyses were performed using the SPSS program (SPSS, 2002).

\section{RESULTS}

\section{Pasture and Heather Supplement}

Available sward height did not differ between plots during the experimental grazing season (Figure 1). Sward height decreased from 25 to $30 \mathrm{~cm}$ at the beginning of the experiment to 8 to $10 \mathrm{~cm}$ at the end of July. In August and September, sward height oscillated between 7 and $8 \mathrm{~cm}$. The botanical composition of available pasture in July was similar in the 4 plots. The percentage of green perennial ryegrass was 37 to $42 \%$, whereas that of other grasses, mainly Agrostis capillaris L., was 30 to $38 \%$. The percentage of white clover ranged from 10 to $18 \%$, whereas dead matter percentage varied between 10 and 16\%. The chemical composition of the pasture in the sampling performed on July 12 revealed a rather low nutritive quality. Crude protein content was $78 \mathrm{~g} / \mathrm{kg}$ of $\mathrm{DM}$, whereas NDF and ADF contents were 670 and $389 \mathrm{~g} / \mathrm{kg}$ of DM, respectively. Average ADL content was also high ( $54 \mathrm{~g} / \mathrm{kg}$ of DM).

Heather species included in the supplement were mainly Erica umbellata L., Erica cinerea L., and Calluna vulgaris $\mathrm{L}$., and their percentages did not change significantly during the experimental period. The nutritive quality of heather samples was lower than in ryegrass-clover pasture, and no differences were found during the grazing season, apart from a slight tendency to decrease from May to September. Crude protein contents ranged from 55 to $70 \mathrm{~g} / \mathrm{kg}$ of DM, and fiber contents were high (NDF 530 to $640 \mathrm{~g} / \mathrm{kg}$ of DM and ADF 440 to $530 \mathrm{~g} / \mathrm{kg}$ of DM). Acid detergent lignin content was very high ( 280 to $400 \mathrm{~g} / \mathrm{kg}$ of DM) because of the woodiness of these plants. Tannin contents of heather did not differ during the grazing season, and values ranged from 7.0 to $8.6 \%$ (in tannic acid equivalents, $\mathrm{SEM}=0.48$ ).

Estimation of diet composition was verified in nonsupplemented goats because values of herbaceous species ranged between 99 and 100\%. In supplemented goats, heather percentage in diet was only 2 to $4 \pm 3.2 \%$ in June; whereas in September, it increased to $20 \pm$ $10.3 \%$ in animals with anthelmintic treatment and 33 $\pm 12.1 \%$ in those without treatment against gastrointestinal nematodes.

\section{Ruminal Fermentation Parameters}

Ruminal fluid ammonia values were only affected ( $P$ $<0.05$ ) by anthelmintic treatment in September (Table 


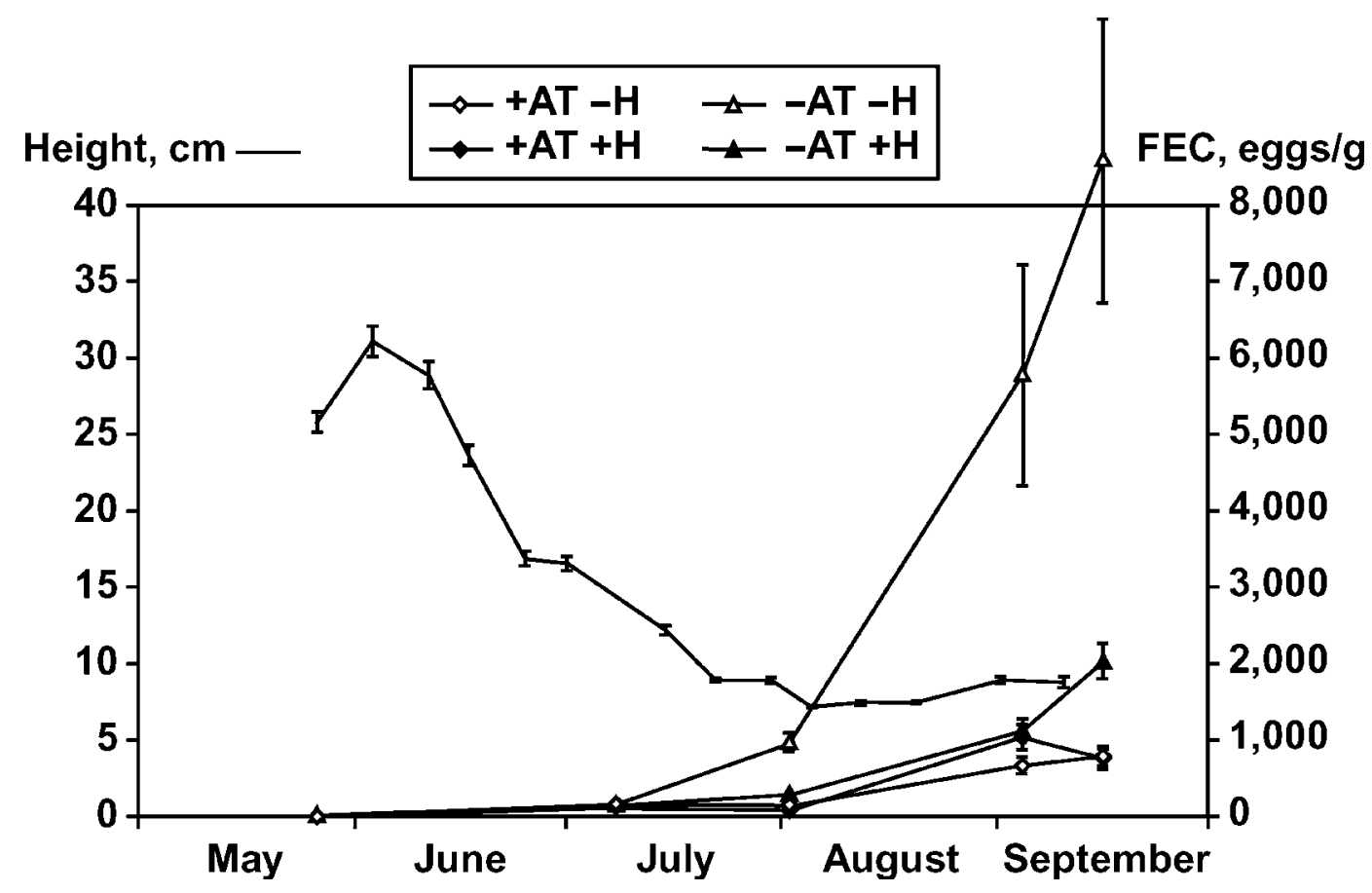

Figure 1. Sward height and fecal gastrointestinal nematode egg counts (FEC) during the experimental grazing period in goats grazing perennial ryegrass-white clover pastures, with or without anthelmintic treatment (+AT, dosed orally with ivermectin every 2 mo; $-\mathrm{AT}$, untreated) and heather supplementation $(+\mathrm{H}$, supplemented with freshly cut heather ad libitum every $3 \mathrm{~d}$; $-\mathrm{H}$, nonsupplemented).

1), and concentrations were greater in dewormed animals. Goats supplemented with heather had lower $(P$ $<0.05$ ) ammonia concentration than those not supplemented, in July and September samplings. The interaction between anthelmintic treatment and heather supplementation was never significant $(P>0.31)$. Concerning ruminal fluid VFA concentrations, no effect of the anthelmintic treatment was observed. However, in September, an anthelmintic treatment $\times$ heather supplementation interaction was detected for the butyrate concentration $(P<0.05)$. In July, there was no evidence of changes in VFA concentrations caused by supplementation with heather. In September, goats consuming heather produced about $16 \%$ more total VFA $(P<0.05)$, which was mostly accounted for by the greater production of acetate $(43.7 \mathrm{vs} .35 .8 \mathrm{mmol} / \mathrm{L})$. However, supplementation with heather decreased isobutyrate and isovalerate concentrations.

\section{Mortality}

The numbers of dead goats in each treatment were 1 in the group supplemented with heather and dosed with anthelmintic, 4 in the group that received neither supplementation nor anthelmintic, and 0 in the other 2 groups. Anthelmintic treatment had no effect on mortality in groups supplemented with heather. However, it was important $(P<0.01)$ in those that received no heather. On the other hand, heather supplementation had no effect in goats treated with anthelmintic, whereas it reduced $(P<0.01)$ mortality in groups that received no anthelmintic treatment. The dead goat from the group supplemented with heather and dosed with anthelmintic had 23,000 and 2,200 nematodes in abomasum and intestine, respectively. The mean parasite burden of the 4 dead goats that received neither heather nor anthelmintic were $14,320,44,920$, and 2,380 parasites in abomasum, small intestine, and large intestine, respectively. Teladorsagia circumcincta and Trichostrongylus spp. were identified in abomasum and intestine; and in 1 goat that received neither heather nor anthelmintic treatment, Chabertia ovina was found in its large intestine.

\section{Fecal Egg Counts and Coprocultures}

Parasite eggs in feces increased during the grazing season in all conditions. This increase was greater in goats that did not receive any treatment (anthelmintic and heather; Figure 1, Table 2). At the beginning of the experiment, mean fecal egg count was lower than 90 eggs/g in all treatment groups. The fecal egg count increased in goats without any treatment during August (3 goats showed fecal egg counts higher than 1,000 eggs/ g). During September, those untreated and nonsupplemented goats presented the greatest mean fecal egg count $(5,808$ and 8,608 eggs/g at 7 th and 14 th dates, respectively) with maximum numbers of 20,500 eggs/g in midSeptember. However, the mean fecal egg count of the other treatment groups were lower than 2,000 
Table 1. Effects of anthelmintic treatment and heather supplementation on ammonia (mg/ $\mathrm{L})$ and VFA (mmol/L) concentrations in the ruminal fluid of goats grazing ryegrassclover pastures

\begin{tabular}{|c|c|c|c|c|c|c|c|c|}
\hline \multirow[b]{2}{*}{ Item } & \multicolumn{2}{|c|}{ Anthelmintic ${ }^{1}$} & \multicolumn{2}{|c|}{ Heather $^{2}$} & \multirow[b]{2}{*}{ SEM $^{4}$} & \multicolumn{3}{|c|}{ Effect $^{3}$} \\
\hline & Yes & No & Yes & No & & $\mathrm{A}$ & $\mathrm{H}$ & $\mathrm{A} \times \mathrm{H}$ \\
\hline \multicolumn{9}{|l|}{ Ammonia } \\
\hline July & 167.0 & 175.1 & 156.8 & 185.3 & 12.52 & $\mathrm{NS}^{5}$ & $<0.05$ & NS \\
\hline September & 226.4 & 147.6 & 148.3 & 235.0 & 18.58 & $<0.01$ & $<0.001$ & NS \\
\hline \multicolumn{9}{|l|}{ Total VFA } \\
\hline July & 43.6 & 37.8 & 40.5 & 41.0 & 3.53 & NS & NS & NS \\
\hline September & 55.3 & 54.7 & 58.9 & 50.9 & 3.51 & NS & $<0.05$ & NS \\
\hline \multicolumn{9}{|l|}{ Acetate } \\
\hline July & 30.5 & 25.6 & 27.7 & 28.4 & 2.50 & $<0.10$ & NS & NS \\
\hline September & 39.8 & 39.9 & 43.7 & 35.8 & 2.83 & NS & $<0.05$ & NS \\
\hline \multicolumn{9}{|l|}{ Propionate } \\
\hline July & 7.16 & 6.21 & 6.60 & 6.80 & 0.68 & NS & NS & NS \\
\hline September & 8.11 & 8.21 & 8.56 & 7.73 & 0.59 & NS & NS & NS \\
\hline \multicolumn{9}{|l|}{ Butyrate } \\
\hline July & 3.74 & 3.62 & 3.76 & 3.61 & 0.36 & NS & NS & NS \\
\hline September & 4.72 & 4.45 & 4.59 & 4.60 & 0.33 & NS & NS & $<0.05$ \\
\hline \multicolumn{9}{|l|}{ Isobutyrate } \\
\hline July & 0.85 & 0.92 & 0.90 & 0.87 & 0.06 & NS & NS & NS \\
\hline September & 0.98 & 0.81 & 0.77 & 1.04 & 0.08 & $<0.10$ & $<0.01$ & NS \\
\hline \multicolumn{9}{|l|}{ Valerate } \\
\hline July & 0.30 & 0.31 & 0.31 & 0.29 & 0.03 & NS & NS & NS \\
\hline September & 0.40 & 0.34 & 0.34 & 0.40 & 0.04 & NS & NS & NS \\
\hline \multicolumn{9}{|l|}{ Isovalerate } \\
\hline July & 1.09 & 1.16 & 1.14 & 1.10 & 0.09 & NS & NS & NS \\
\hline September & 1.24 & 1.02 & 0.95 & 1.34 & 0.11 & NS & $<0.01$ & NS \\
\hline
\end{tabular}

${ }^{1}$ Dosed orally every 2 mo with ivermectin $(2 \mathrm{mg} / \mathrm{kg}$ of BW).

${ }^{2}$ Supplemented every $3 \mathrm{~d}$ with freshly cut heather ad libitum.

${ }^{3} \mathrm{~A}=$ Anthelmintic; $\mathrm{H}=$ heather.

${ }^{4}$ Based on 40 observations.

${ }^{5} \mathrm{NS}=$ Not significant $(P>0.10)$.

eggs/g in that period, especially in groups dosed with anthelmintic. In addition, goats dosed with anthelmintic showed a similar increase in fecal egg count during the entire experimental period. When anthelmintictreated groups were compared with the group that re- ceived heather, the fecal egg counts were similar during June and July. In August, goats that received only heather showed a greater mean fecal egg count (301 eggs/g), which increased in September (2,029 and 2,340 eggs/g in early and midSeptember, respectively), but

Table 2. Effects of anthelmintic treatment and heather supplementation on fecal gastrointestinal nematode egg counts (eggs/g, log-transformed values in brackets) of goats grazing ryegrass-clover pastures (from May to September)

\begin{tabular}{|c|c|c|c|c|c|c|c|c|}
\hline \multirow{2}{*}{$\begin{array}{r}\text { Anthelmintic }^{1} \\
\text { Heather }^{2}\end{array}$} & \multirow{2}{*}{$\begin{array}{l}\text { Yes } \\
\text { Yes }\end{array}$} & \multirow{2}{*}{$\begin{array}{l}\text { Yes } \\
\text { No }\end{array}$} & \multirow{2}{*}{$\begin{array}{l}\text { No } \\
\text { Yes }\end{array}$} & \multirow{2}{*}{$\begin{array}{l}\text { No } \\
\text { No }\end{array}$} & \multirow[b]{2}{*}{$\mathrm{SEM}^{3}$} & \multicolumn{3}{|c|}{ Effect $^{4}$} \\
\hline & & & & & & A & $\mathrm{H}$ & $\mathrm{A} \times \mathrm{H}$ \\
\hline 25 May & $\begin{array}{l}30 \\
(0.53)\end{array}$ & $\begin{array}{l}5 \\
(0.36)\end{array}$ & $\begin{array}{l}15 \\
(0.52)\end{array}$ & $\begin{array}{l}36 \\
(0.98)\end{array}$ & 0.129 & $\mathrm{NS}^{5}$ & NS & NS \\
\hline 8 July & $\begin{array}{l}117 \\
(1.64)\end{array}$ & $\begin{array}{l}146 \\
(2.06)\end{array}$ & $\begin{array}{l}158 \\
(2.14)\end{array}$ & $\begin{array}{l}172 \\
(2.16)\end{array}$ & 0.079 & $<0.10$ & NS & NS \\
\hline 2 August & $\begin{array}{l}73 \\
(1.63)\end{array}$ & $\begin{array}{l}153 \\
(1.91)\end{array}$ & $\begin{array}{l}302 \\
\quad(2.35)\end{array}$ & $\begin{array}{l}980 \\
(2.92)\end{array}$ & 0.120 & $<0.001$ & $<0.05$ & NS \\
\hline 7 September & $\begin{array}{l}1,036 \\
(2.80)\end{array}$ & $\begin{array}{l}673 \\
(2.62)\end{array}$ & $\begin{array}{l}1,125 \\
(2.90)\end{array}$ & $\begin{array}{l}5,808 \\
\quad(3.52)\end{array}$ & 0.095 & $<0.01$ & NS & $<0.05$ \\
\hline 14 September & $\begin{array}{l}778 \\
(2.68)\end{array}$ & $\begin{array}{l}795 \\
(2.78)\end{array}$ & $\begin{array}{l}2,029 \\
\quad(3.22)\end{array}$ & $\begin{array}{l}8,608 \\
\quad(3.66)\end{array}$ & 0.097 & $<0.001$ & $<0.10$ & NS \\
\hline
\end{tabular}

${ }^{1}$ Dosed orally every 2 mo with ivermectin $(2 \mathrm{mg} / \mathrm{kg}$ of $\mathrm{BW})$.

${ }^{2}$ Supplemented every $3 \mathrm{~d}$ with freshly cut heather ad libitum.

${ }^{3}$ Based on 40 observations.

${ }^{4} \mathrm{~A}=$ Anthelmintic; $\mathrm{H}=$ heather.

${ }^{5} \mathrm{NS}=$ Not significant $(P>0.10)$. 


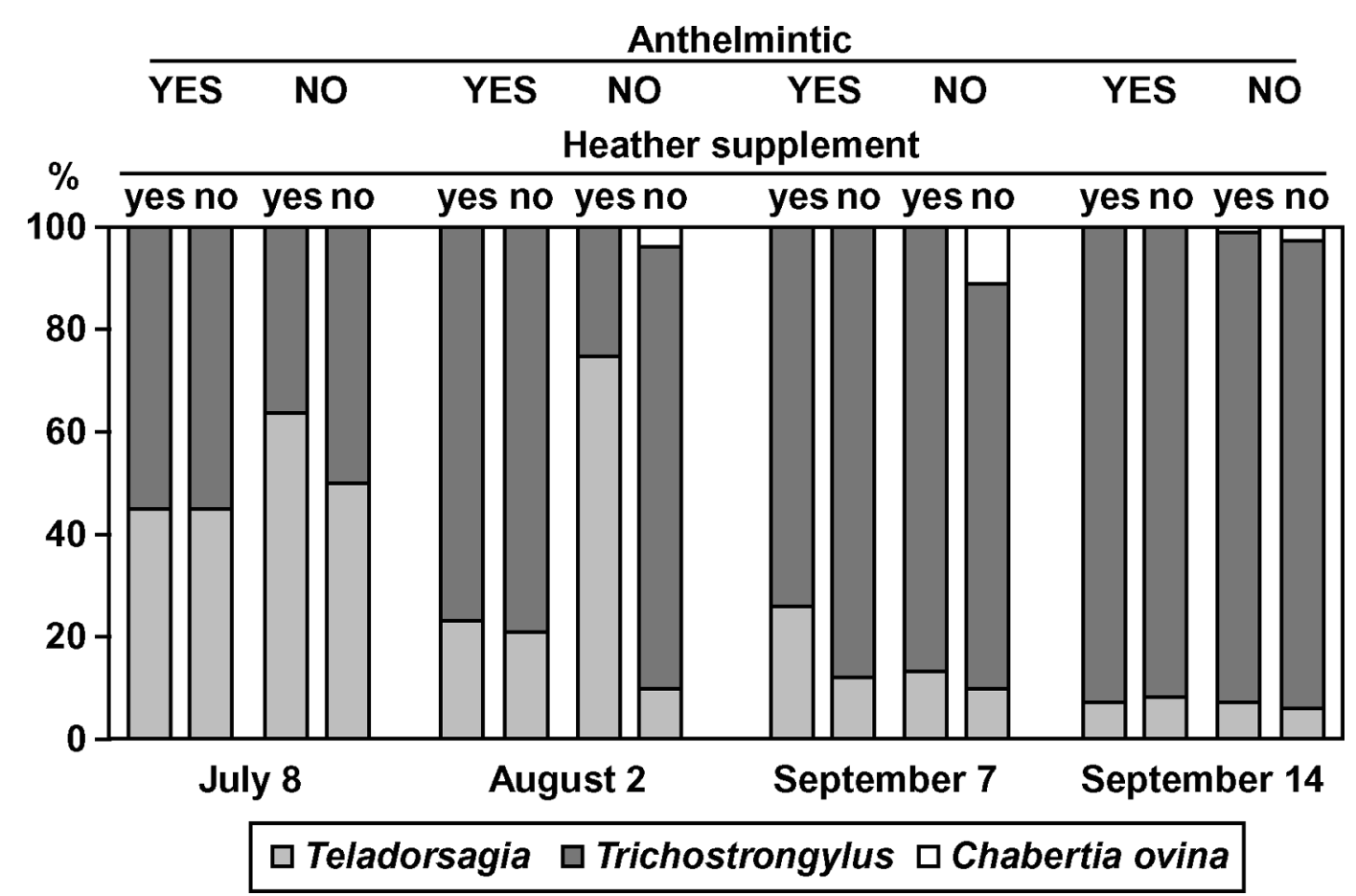

Figure 2. Nematode genera, \%, identified on third-stage larvae obtained monthly in coprocultures from goats grazing ryegrass-clover pastures with or without anthelmintic treatment (ivermectin oral dose every 2 mo) and supplemented or not with freshly cut heather ad libitum every $3 \mathrm{~d}$.

goats from groups dosed with anthelminitic showed mean fecal egg count lower than 800 eggs/g in the last control. No effect of heather supplementation was observed in goats treated with anthelmintic, although a reduction $(P<0.01)$ in fecal egg count was observed in August and September in those receiving no anthelmintic treatment but supplemented with heather. The interaction between anthelmintic treatment and heather supplementation was only significant $(P<0.05)$ in September sampling.

Nematodes identified were Teladorsagia circumcincta, Trichostrongylus spp., and Chabertia ovina. Trichostrongylus spp. were the gastrointestinal nematodes more frequently identified over the whole experimental period (Figure 2). Trichostrongylus spp. was the predominant genus in July in all treatment groups (55\%), except in nondewormed and heather supplemented treatment (36\%), where the predominant nematode was Te. circumcincta in July (64\%) and August (75\%). From August to midSeptember the Trichostrongylus spp. percentage increased until $90 \%$. The percentage of Te. circumcincta decreased in all treatments from August (18\%) to September (7\%), but in nondewormed and heather supplemented animals the only decrease occurred in September. Chabertia ovina was detected from August, but in a small percentage (less than 4\%) compared with Trichostrongylus and Te. circumcinta, and only in goats from groups that did not receive the anthelmintic treatment.

\section{Body Weight Changes}

In the overall experimental grazing season (May through September), these nonlactating does lost 6 to $9 \mathrm{~g} / \mathrm{d}$, except in the group not supplemented and without anthelmintic treatment, which lost $25 \mathrm{~g} / \mathrm{d}$ (Table 3). In period 1 , BW gains were lower $(P<0.05)$ in the control group. Differences between treatments were, however, lower in period 2 probably due to the 4 does that died in the control treatment (goats without anthelmintic treatment and without heather supplement). These 4 does lost weight $(-99 \mathrm{~g} / \mathrm{d})$ in the previous sampling, whereas the other 6 does in the same group gained BW $(30 \mathrm{~g} / \mathrm{d} ; P<0.05)$. The interaction between treatments was not significant. There were no differences in BCS between treatments (Table 3 ).

\section{Correlations}

The study of relationships between the percentage of heather in the diet, fecal egg counts, and BW changes in goats that did not receive anthelmintic treatment in general showed a significant negative correlation between the percentage of heather in the diet and fecal egg count in August $(\mathrm{r}=-0.59, P<0.05)$ and September $(\mathrm{r}=-0.49, P<0.10)$. Positive correlation coefficients were found for the same goats between heather percentage in diet and the BW changes during the grazing season $(\mathrm{r}=0.54, P<0.05)$. Therefore, the correlation coefficient between BW changes and fecal egg count 
Table 3. Effects of anthelmintic treatment and heather supplementation on BW and BCS changes of goats grazing ryegrass-clover pastures (from May to September) ${ }^{1}$

\begin{tabular}{lccccc}
\hline \multicolumn{1}{c}{$\begin{array}{c}\text { Anthelmintic } \\
\text { Heather supplementation }\end{array}$} & $\begin{array}{c}\text { Yes } \\
\text { Yes }\end{array}$ & $\begin{array}{c}\text { Yes } \\
\text { No }\end{array}$ & $\begin{array}{c}\text { No } \\
\text { Yes }\end{array}$ & $\begin{array}{c}\text { No } \\
\text { No }\end{array}$ & SEM $^{4}$ \\
\hline Initial BW in 25 May, kg & 31.2 & 31.5 & 31.1 & 30.8 & 0.88 \\
BW change, g/d & & & & & \\
Period 1 (May-August) & 50 & 44 & 38 & 17 & 5.42 \\
Period 2 (August-September) & -102 & -94 & -76 & -93 & 8.53 \\
Whole season (May-September) & -8 & -9 & -6 & -25 & 3.90 \\
Initial BCS in 25 May & 2.93 & 3.00 & 3.00 & 2.98 & 0.081 \\
BCS change (May-September) & -0.12 & -0.02 & 0.02 & -0.32 & 0.072 \\
\hline
\end{tabular}

\footnotetext{
${ }^{1}$ All effects nonsignificant $(P>0.10)$ except for anthelmintic effect on BW change during period $1(P<$ $0.10)$.

${ }^{2}$ Dosed orally every 2 mo with ivermectin $(2 \mathrm{mg} / \mathrm{kg}$ of BW).

${ }^{3}$ Supplemented every $3 \mathrm{~d}$ with freshly cut heather ad libitum.

${ }^{4}$ Based on 40 observations.
}

was negative $(\mathrm{r}=-0.62, P<0.05)$. Considering all goats, the correlation coefficient between percentage of heather in the diet and ammonia concentration in the rumen in September was negative $(\mathrm{r}=-0.66, P<0.001)$.

\section{DISCUSSION}

The current study was carried out to investigate the effect of heather intake by nonlactating Cashmere goats on pasture on gastrointestinal fecal egg counts, some ruminal fermentation parameters, and BW changes. Several reports have shown that plant secondary metabolites, such as tannins, could affect biology of the gastrointestinal nematodes, mainly by decreasing fecal egg counts, and could, therefore, contribute to modulating the epidemiology of these parasitic diseases (Athanasiadou et al., 2003; Hoste et al., 2005). The reduction in nematode egg excretion observed in goats supplemented with heather confirmed previous experiments from our group (Osoro et al., 2006) and agree with studies involving supplementation of plant secondary metabolites to experimentally infected sheep (Niezen et al., 1998; Athanasiadou et al., 2000, 2001, 2005) and goats that were naturally (Paolini et al., 2003b, 2005; Min et al., 2005) and experimentally infected (Madibela and Jansen, 2003; Paolini et al., 2003a,c).

The fecal egg count reduction level in heather supplemented goats compared with control goats was maximum in September $(75 \%)$ and greater than that found in the previous grazing season (40\%, Osoro et al., 2006) and other experiments (50 to 60\%) reported by Paolini et al. (2003a,c) with goats experimentally infected with gastrointestinal nematodes (Trichostrongylus colubriformis and Teladorsagia circumcincta, and Haemonchus contortus, respectively) but similar (near 80\%) to that observed by Shaik et al. (2006) feeding goats infected with $H$. contortus, with Sericea lespedeza hay. Probably different nematode species could respond differently to tannins. The reduction in fecal egg count of established nematode population has been associated with reduced fecundity of the worms (Paolini et al., 2003a,c, 2005). The progressive reduction in fecal egg count in those goats supplemented with heather compared with control goats during the grazing season may be accounted for by the increased heather percentage in the diet because the fecal egg count reduction level was even greater in goats receiving no anthelmintic treatment. The greater intake of heather in untreated goats compared with treated goats could be related to a greater infection risk. Hoste et al. (2001) found a negative relationship between the time spent browsing and fecal egg counts in 2 goat breeds (Angora and French Alpine). The low CP content (5 to 7\%) of heather could not positively affect the control of parasites (Houdijk and Athanasiadou, 2003). It is worth mentioning that Hoste et al. (2005) recently indicated no clear answer to questions about the role of dietary protein supplementation on the resilience and resistance of growing goats to gastrointestinal nematodes. No conclusions can be drawn about the mechanism responsible for the reduction in fecal egg count because the naturally infected goats were not killed at the end of the experiment and the number of dead goats in September was very low to compare parasite burden or female fecundity between treatments.

Consumption of heather was associated with an apparent greater resistance of Cashmere goats to gastrointestinal nematode infection. This conclusion is supported by the fact that the 4 goats that died had not received heather or anthelmintic treatment. In addition, all other goats of that group (control) had severe diarrhea at the end of the experiment. An improved resistance and resilience of the host have been reported in sheep (Niezen et al., 1998) and goats (Paolini et al., 2005) fed tannin-containing plants.

The constant tannin content (7.0 to $8.6 \mathrm{~g}$ of tannic acid equivalents $/ 100 \mathrm{~g}$ of $\mathrm{DM}$ ) in the heather offered from late May to September is similar to other tannincontaining species (Ericaceae species; Frutos et al., 2002). The estimated maximum amount of tannins the goats consumed was $2.8 \%$ DMI (tannic acid equivalents), which is considered a low to moderate intake. A moderate level (5 to 6\% DMI) of tannins fed to experimentally infected goats reduced fecal egg counts and 
nematode female fertility (Paolini et al., 2003a,c). Likewise, tannins (6\% DMI) fed to experimentally infected (T. colubriformis) sheep reduced fecal egg counts (Athanasiadou et al., 2000; Butter et al., 2000).

Treatment differences were also observed in the parameters of ruminal fermentation (ammonia and VFA concentrations). Most likely, the goats' protein requirements were not met, considering the low CP content of the diet. However, all ammonia concentrations observed in this study (see Table 1) were greater than the $100 \mathrm{mg} / \mathrm{L}$ reported by van Soest (1994) as optimal for efficiency of amino acid synthesis and microbial growth. Rumen ammonia concentrations were lower in goats supplemented with heather, which agrees with the well-known effect of tannins on the proteolysis of feed protein and the subsequently lowered concentration of ammonia in ruminal fluid (Waghorn, 1996). In the sampling carried out in September, the correlation coefficient between the percentage of heather in the diet and the rumen ammonia concentration was negative $(r=$ $-0.66, P<0.001)$. This reduction in ammonia caused by tannins is speculated to result in greater postruminal protein availability for goats supplemented with tannin-rich plants (Waghorn et al., 1987; Barry and McNabb, 1999). In September, lower ruminal ammonia concentrations were also observed in the goats receiving no anthelmintic treatment but supplemented with heather.

Mean VFA concentrations were affected by heather supplementation but not by anthelmintic treatment. In the sampling carried out in September, total VFA concentrations were found to be greater in goats consuming heather (58.9 vs. $50.9 \mathrm{mmol} / \mathrm{L}, P<0.05$ ), which suggests that fermentation might have been more efficient in these animals. The lack of differences in July can probably be attributed to the low proportion of heather (2 to $4 \%$ ) in the diet. In agreement with the lower concentration of ammonia, the reduced concentrations of branched chain VFA (isobutyrate and isovalerate) in goats supplemented with heather reflect the effect of tannins on proteolysis. Thus, although some studies have shown the antinutritional effect of tannins (Makkar, 2003), our results suggest that the amount of tannins consumed by the animals offered heather was insufficient to elicit a negative response. Beneficial effects of tannins when consumed in moderate concentrations have also been reported on many occasions (Barry and McNabb, 1999).

The negative BW changes in grazing period 2 were mainly related to nutritional or parasite infection factors, or both. The first assumption is associated with the poor nutritive quality $(7.8 \% \mathrm{CP})$ of available pasture, which consisted of high percentages of ryegrass flower stems and dead matter. These results support previous observations (Hughes et al., 1984; Lu, 1988; Merchant and Riach, 1994) that goats select high quality pastures and contradict the suggestion that these animals can maintain their BW with only fibrous stemmy material. In goats, in contrast to sheep or cattle, the linear rela- tionship between green sward height and BW change has been reported for heights between 3 and $11 \mathrm{~cm}$ (Merchant and Riach, 1994; Osoro and Martínez, 1994), between 2 and $7 \mathrm{~cm}$ (McCall and Lambert, 1987), and between 6 and $11 \mathrm{~cm}$ (Radcliffe et al., 1991). Therefore, after the end of July, when the sward height decreased to 7 to $8 \mathrm{~cm}$, food intake and BW gains would have likely been limited not only by the quality of pasture but also by its availability. The other factor affecting BW gain would be the increase in parasite burden during the grazing season. The negative relationship between gastrointestinal nematode infections and BW change has been reported in experimental and natural infections (Coop and Kyriazakis, 2001).

The present work was conducted under practical conditions, trying to simulate conditions of extensive production systems of a less-favored area where availability of forage may be limited during the summer. Results agree with those from a previous study (Osoro et al., 2007) where grazing goats supplemented with heather showed a reduction in fecal egg count and a better performance compared with nonsupplemented animals. In a recent review on the use of tannin-containing plants for control of gastrointestinal helminths, Githiori et al. (2006) indicated that the lack of nonparasitized animals in the experimental designs of grazing studies makes it impossible to differentiate the actual effects of tannin consumption.

Results of the present experiment demonstrate that heather supplementation to grazing nonlactating Cashmere goats was beneficial in host resilience without any apparent nutritional cost. Heather availability in the vegetation might represent a sustainable method to control gastrointestinal nematode infections in an extensive goat production system based on grazing perennial ryegrass-white clover pastures.

\section{LITERATURE CITED}

AOAC. 1990. Official Methods of Analysis. 14th ed. Assoc. Off. Anal. Chem., Washington, DC.

Athanasiadou, S., I. Kyriazakis, F. Jackson, and R. L. Coop. 2000. Consequences of long-term feeding with condensed tannins on sheep parasitised with Trichostrongylus colubriformis. Int. J. Parasitol. 30:1025-1033.

Athanasiadou, S., I. Kyriazakis, and F. Jackson. 2003. Can plant metabolites have a role in controlling gastrointestinal nematode parasitism in small ruminants? Proc. Satellite Symp. on Secondary Compounds and Browse Utilization, VI Int. Symp. Nutrition of Herbivores, Univ. Aut. Yucatán, Mérida, México: 16-25.

Athanasiadou, S., I. Kyriazakis, F. Jackson, and R. L. Coop. 2001. Direct anthelmintic effects of condensed tannins towards different gastrointestinal nematodes of sheep: In vitro and in vivo studies. Vet. Parasitol. 99:205-219.

Athanasiadou, S., O. Tzamaloukas, I. Kyriazakis, and F. Jackson. 2005. Testing for direct anthelmintic effects of bioactive forages against Trichostrongylus colubriformis in grazing sheep. Vet. Parasitol. 127:233-243.

Barry, T. N., and W. C. McNabb. 1999. The implications of condensed tannins on the nutritive value of temperate forages fed to ruminants. Br. J. Nutr. 81:263-272.

Barthram, G. T. 1986. Experimental techniques: The HFRO swardstick. The Hill Farming Research Organisation Biennial 
Report 1984-85, HFRO, Bush Estate, Penicuik, Midlothian, UK: 29-30.

Butter, N. L., J. M. Dawson, D. Wakelin, and P. J. Buttery. 2000. Effect of dietary tannin and protein concentration on nematode infection (Trichostrongylus colubriformis) in lambs. J. Agric. Sci. 134:89-99.

Carro, M. D., S. López, C. Valdés, and F. J. Ovejero. 1999. Effect of DL-malate on mixed ruminal microorganism fermentation using the rumen simulation technique (RUSITEC). Anim. Feed Sci. Technol. 79:279-288.

Coop, R. L., and I. Kyriazakis. 2001. Influence of host nutrition on the development and consequences of nematode parasitism in ruminants. Trends Parasitol. 17:325-330.

Dove, H., and A. D. Moore. 1995. Using a lesat-squares optimisation procedure to estimate diet composition based on the alkanes of plant cuticular wax. Aust. J. Agric. Res. 46:1535-1544.

Ferreira, L. M. M., M. Oliván, U. García, M. A. M. Rodrigues, and K. Osoro. 2005. Validation of the alkane technique to estimate diet selection of goats grazing heather-gorse vegetation communities. J. Sci. Food Agric. 85:1636-1646.

Frutos, P., G. Hervás, F. J. Giráldez, M. Fernández, and A. R. Mantecón. 2000. Digestive utilization of quebracho-treated soya bean meal in sheep. J. Agric. Sci. 134:101-108.

Frutos, P., G. Hervás, G. Ramos, F. J. Giráldez, and A. R. Mantecón. 2002. Condensed tannin content of several shrub species from a mountain area in northern Spain and its relationship to various indicators of nutritive value. Anim. Feed Sci. Technol. 95:215-226.

Githiori, J. B., S. Athanasiadou, and S. M. Thamsborg. 2006. Use of plants in novel approaches for control of gastrointestinal helminths in livestock with emphasis on small ruminants. Vet. Parasitol.

Goering, M. K., and P. J. van Soest. 1970. Forage fiber analysis (Apparatus, Reagents, Procedures And Some Applications). Agric. Handbook No. 379, ARS-USDA, Washington, DC.

Grant, S. A. 1981. Sward components. Pages 71-92 in Sward Measurement Handbook. J. Hodgson, R. D. Baker, A. Davies, A. S. Laidlaw, and J. D. Leaver, ed. British Grassland Society, Hurley, Maidenhead, Berkshire, UK.

Hoste, H., H. Leveque, and Ph. Dorchies. 2001. Comparison of nematode infections of the gastrointestinal tract in Angora and dairy goats in a rangeland environment: relations with the feeding behaviour. Vet. Parasitol. 101:127-135.

Hoste, H., J. F. Torres-Acosta, V. Paolini, A. Aguilar-Caballero, E. Etter, Y. Lefrileux, C. Chartier, and C. Broqua. 2005. Interactions between nutrition and gastrointestinal infections with parasitic nematodes in goats. Small Rumin. Res. 60:141-151.

Houdijk, J. G. M., and S. Athanasiadou. 2003. Direct and indirect effects of host nutrition on ruminant gastrointestinal nematodes. Pages 213-236 in Matching Herbivore Nutrition to Ecosystems Biodiversity. L. 't Mannetje, L. Ramírez, C. Sandoval-Castro, and J. C. Ku-Vera, ed. VI Int. Symp. Nutrition of Herbivores, Univ. Aut. Yucatán, Mérida, México.

Hughes, T. P., A. R. Sykes, and D. P. Poppi. 1984. Diet selection of young ruminants in late spring. Proc. N. Z. Soc. Anim. Prod. 44:109-112.

Jackson, F., and R. L. Coop. 2000. The development of anthelmintic resistance in sheep nematodes. Parasitol. 120:95-107.

Lu, C. D. 1988. Grazing behaviour and diet selection of goats. Small Rumin. Res. 1:205-216.

Madibela, O. R., and K. Jansen. 2003. The use of indigenous parasitic plant (Viscum verrucosum) in reducing faecal egg counts in female Tswana goats. Livest. Res. Rural Dev. 15 (9). http://www.cipav.org.co/lrrd//rrd15/9/madi159.htm Accessed Jan. 15, 2006.

MAFF. 1978. Manual of Veterinary Parasitological Techniques. Tech. Bull. No. 18. Ministry of Agriculture, Fisheries and Food, London, UK.

Makkar, H. P. S. 2003. Effects and fate of tannins in ruminant animals, adaptation to tannins, and strategies to overcome detrimental effects of feeding tannin-rich feeds. Small Rumin. Res. 49:241-256.
Makkar, H. P. S., M. Blummel, N. K. Borowy, and K. Becker. 1993. Gravimetric determination of tannins and their correlations with chemical and protein precipitation methods. J. Sci. Food Agric. 61:161-165.

Mayes, R. W., C. S. Lamb, and P. M. Colgrove. 1986. The use of dosed and herbage n-alkanes as markers for the determination of herbage intake. J. Agric. Sci. 107:161-170.

McCall, D. G., and M. G. Lambert. 1987. Pasture feeding of goats. Pages 105-109 in Livestock Feeding on Pasture. A. M. Nicol, ed. N. Z. Soc. Anim. Prod. Occ. Publ. No. 10.

McLeod, M. N. 1974. Plant tannins-Their role in forage quality. Nutr. Abst. Rev. 44:803-812.

Merchant, M., and D. J. Riach. 1994. The intake and performance of cashmere goats grazing sown swards. Grass and Forage Sci. 49:429-437.

Min, B. R., S. P. Hart, D. Miller, G. M. Tomita, E. Loetz, and T. Sahlu. 2005. The effect of grazing forage containing condensed tannins on gastro-intestinal parasite infection and milk composition in Angora does. Vet. Parasitol. 130:105-113.

Niezen, J. H., H. A. Robertson, G. C. Waghorn, and W. A. G. Charleston. 1998. Production, faecal egg counts and worm burdens of ewe lambs which grazed six contrasting forages. Vet. Parasitol. $80: 15-27$.

Oliván, M., and K. Osoro. 1999. Effect of temperature on alkane extraction from faeces and herbage. J. Agric. Sci. 132:305-312.

Osoro, K., A. Benito-Peña, P. Frutos, U. García, L. M. Ortega-Mora, R. Celaya, and I. Ferre. 2007. The effect of heather supplementation on faecal egg counts of gastrointestinal nematodes and live weight changes in Cashmere and local Celtiberic goats on pasture. Small Rumin. Res. 67:184-191.

Osoro, K., and A. Martínez. 1994. Efecto de la presión de pastoreo y del porcentaje de pasto mejorado disponible en el rendimiento animal de ovinos y caprinos. Proc. XXXIV Reunión Científica de la SEEP, Santander, Spain: 337-342.

Osoro, K., A. Martínez, M. Llorente, and J. Uriarte. 1995. Efecto del manejo del pastoreo en el nivel de excreción de huevos de nematodos de ovinos y caprinos. ITEA, VI Jornadas sobre Producción Animal, Vol. Extra No. 16. AIDA, Zaragoza, Spain: 575-577.

Osoro, K., J. M. Vassallo, R. Celaya, and A. Martínez. 1999. Livestock production systems and the vegetation dynamics of Less Favoured Areas (LFAs): Developing viable systems to manage semi-natural vegetation in temperate LFAs in Spain. Pages 133143 in Livestock Production in the European Less Favoured Areas. J. P. Laker, and J. A. Milne, ed. MLURI, Aberdeen, UK.

Paolini, V., J. P. Bergeaud, C. Grisez, F. Prevot, Ph. Dorchies, and H. Hoste. 2003a. Effects of condensed tannins on goats experimentally infected with Haemonchus contortus. Vet. Parasitol. 113:253-261.

Paolini, V., Ph. Dorchies, and H. Hoste. 2003b. Effects of sainfoin hay on gastrointestinal nematode infections in goats. Vet. Rec. 152:600-601.

Paolini, V., A. Frayssines, F. De la Farge, Ph. Dorchies, and H. Hoste. 2003c. Effects of condensed tannins on established populations and on incoming larvae of Trichostrongylus colubriformis and Teladorsagia circumcincta in goats. Vet. Res. 34:331-339.

Paolini, V., F. De la Farge, F. Prevot, Ph. Dorchies, and H. Hoste. 2005. Effects of the repeated distribution of sainfoin hay on the resistance and the resilence of goats naturally infected with gastrointestinal nematodes. Vet. Parasitol. 127:277-283.

Radcliffe, J. E., R. J. Townsend, and D. B. Baird. 1991. Mixed and separate grazing of sheep and goats at two stocking rates. N. Z. J. Agric. Res. 34:167-176.

Russel, A. J. F. 1990. Body condition scoring of goats. Scottish Cashmere Producers Association Newsletter 10:3.

Shaik, S. A., T. H. Terrill, J. E. Miller, B. Kouakou, G. Kannan, R. M. Kaplan, J. M. Burke, and J. A. Mosjidis. 2006. Sericea lespedeza hay as a natural deworming agent against gastrointestinal nematode infection in goats. Vet. Parasitol. 139:150-157.

Sykes, A. R. 1994. Parasitism and production in farm animals. Anim. Prod. 59:155-172.

SPSS. 2002. User's Guide, SPSS 1.5. SPSS Inc., Ireland. 
van Soest, P. J., J. B. Robertson, and B. A. Lewis. 1991. Methods for dietary fiber, neutral detergent fiber, and nonstarch polysacharides in relation to animal nutrition. J. Dairy Sci. 74:3583-3597.

van Soest, P. J. 1994. Nutritional Ecology of the Ruminant. 2nd ed. Cornell University Press, Ithaca, NY.

van Wyk, J. A., J. Cabaret, and L. M. Michael. 2004. Morphological identification of nematode larvae of small ruminants and cattle simplified. Vet. Parasitol. 119:277-306.

Waghorn, G. 1996. Condensed tannins and nutrient absorption from the small intestine. Pages 175-194 in Proc. Can. Soc. Anim. Sci. Annual Meeting, Lethbridge, Canada.
Waghorn, G. C., M. J. Ulyatt, A. John, and M. T. Fisher. 1987. The effects of condensed tannins on the site of digestion of amino acids and other nutrients in sheep fed on Lotus corniculatus L. Br. J. Nutr. 57:115-126.

Waller, P. J. 1999. International approaches to the concept of integrated control, of nematode parasites of livestock. Int. J. Parasitol. 29:155-164.

Weatherburn, M. W. 1967. Phenol-hypochlorite reaction for determination of ammonia. Anal. Chem. 39:971-974. 